\title{
Paleoenvironmental characterization of a Lower Cretaceous section of the Recôncavo Basin, Bahia, Brazil
}

\author{
Diego Nery do Amaral ${ }^{*}$ (D), José Roberto Cerqueira ${ }^{1}$ (D), Consuelo Lima Navarro de Andrade ${ }^{2}$ (D), \\ Hélio Jorge Portugal Severiano Ribeiro ${ }^{3}$ (D), Karina Santos Garcia' (D), Flávia Lima e Cima Miranda' (D),

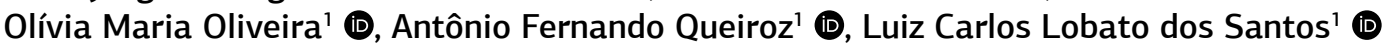

\begin{abstract}
The objective of this work was to evaluate the paleodepositional conditions and potential for the hydrocarbons generation of the outcropping shales in the Southern Compartment of the Recôncavo Basin, indicative of the Candeias and Maracangalha Formations (Lower Cretaceous), from the organic geochemical characterization and analysis of palinofacies. For this, 23 samples of outcrops were collected near the cities of Santo Amaro, São Francisco do Conde and Simões Filho, State of Bahia, Brazil. All samples were analyzed for total organic carbon (TOC), total sulfur, insoluble residue, Rock-Eval pyrolysis, whole oil chromatography, stable isotopes of oxygen, organic and inorganic carbon, saturated biomarkers and palynofacies, performed at the Center of Excellence in Geochemistry of the Institute of Geosciences of the Universidade Federal da Bahia (Lepetro), Brazil. The parameters provided by the geochemical analyzes indicate significant differences between the outcrops under study, mainly regarding the quantity and the quality of the organic matter, thus configuring a difference in the conditions of production and preservation of the organic matter during the time of deposition of the shales. There are layers rich in organic carbon, containing well-preserved type I kerogen, indicating anoxic depositional conditions. In contrast, poor layers of organic content, containing residual kerogen (type IV), occur, reflecting oxidizing conditions of the depositional environment. The observed differences suggest that the variability of the geochemical properties of the organic matter reflects the climatic variations occurred during the deposition of the sediments of the Candeias and Maracangalha Formations. As a consequence, there are levels with potential for generation and levels with no potential for hydrocarbon generation.
\end{abstract}

KEYWORDS: Recôncavo Basin; organic geochemistry; potential generator; biomarkers; palynofacies.

\section{INTRODUCTION}

The Recôncavo Basin is located in the State of Bahia, northeastern Brazil, comprising an area of approximately $11,500 \mathrm{~km}^{2}$, and corresponds to the southern portion of the RecôncavoTucano-Jatobá Rift (RTJ) (Fig. 1). The RTJ system can be understood as an aulacogenic segment, the origin of which is associated with the Gondwana fragmentation during the Mesozoic period, which is responsible for the individualization of the current South American and African continents, and is believed to have affected the portion where the RTJ rite in the Cretaceous (Santos et al. 1990, Milhomem et al. 2003). The sedimentary filling of the Recôncavo Basin was controlled, among other factors, by the tectonic activity responsible for the continental rift, showing rocks associated with this event that

\footnotetext{
${ }^{1}$ Universidade Federal da Bahia - Salvador (BA), Brazil. E-mails:
d.nery9@gmail.com, jrkcerq@gmail.com, karina.ksg4@gmail.com,

${ }^{1}$ Universidade Federal da Bahia - Salvador (BA), Brazil. E-mails:
d.nery9@gmail.com, jrkcerq@gmail.com, karina.ksg4@gmail.com, cimaflavia@gmail.com,olivia@ufba.br, queiroz@ufba.br, lclsantos@ufba.br

${ }^{2}$ Departamento de Ciências Exatas (DEXA), Universidade Estadual de Feira de Santana - Bahia, Brazil. E-mail: consuelonavarro87@gmail.com ${ }^{3}$ Universidade Estadual do Norte Fluminense Darcy Ribeiro - Rio de Janeiro (RJ), Brazil. E-mail: severiano.geologo@gmail.com

${ }^{*}$ Corresponding author.
} under the terms of the Creative Commons license.

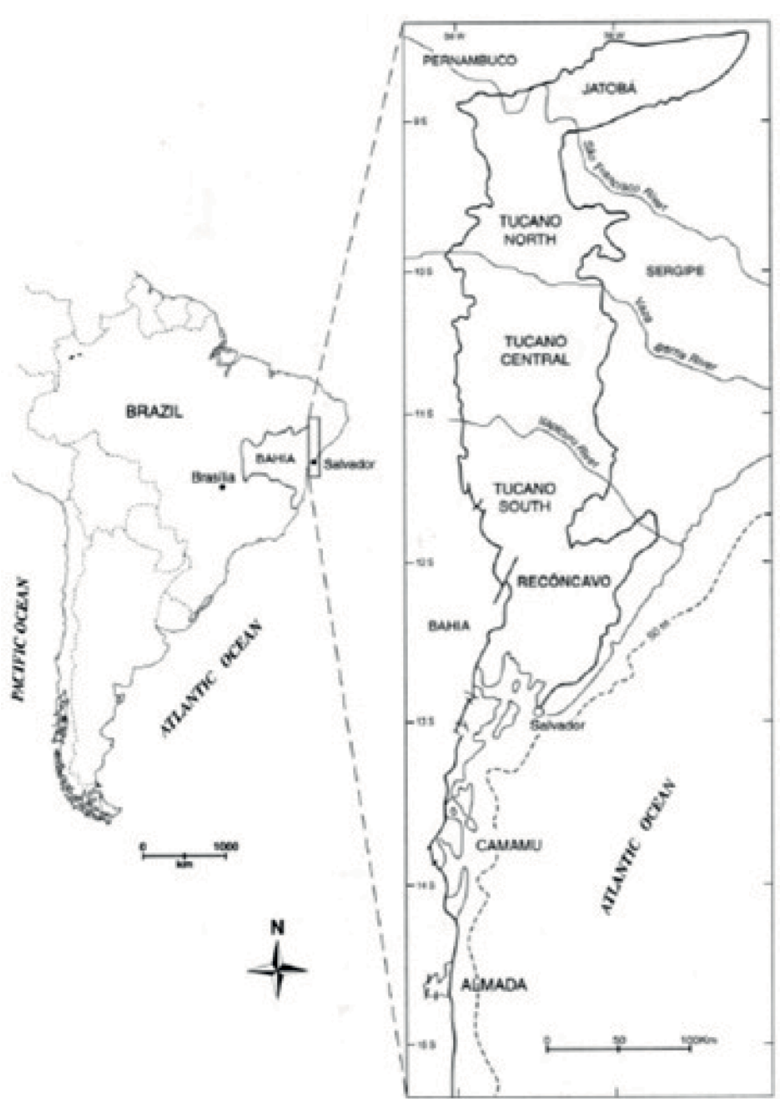

Source: modified from Santos et al. (1990).

Figure 1. Location map of the Recôncavo Basin. 
date from the Lower Cretaceous, from approximately 145 million years to approximately 115 million years.

The deposition of the Candeias Formation ( 140 million years) occurred in a context of increased tectonic activity added to the context with predominance of climatic humidification, generating conditions for the development of deep lakes, marking the beginning of the phase rifte of the basin, in Berriasian. In this scenario, there is initially transgression of the dark limbs of the Tauá Member, which are overlapped by gray-green shales with limestone intercalations of the Gomo Member (Caixeta et al. 1994).

During this phase, with configuration of infilled basin, in the depocenters were deposited longitudinal and transverse turbidites, caused by seismic tremors, together with lake shales (Da Silva et al. 2000, Magnavita et al. 2005).

Along the Valangian/Hauterivian, the tectonic attenuation and the increase of the sedimentary contribution resulted in the reduction of the depositional gradients, with progressive sedimentation of the depocenters. Distal delta systems were formed by depositing deposits of gravitational fluxes (Caruaçu and Pitanga Members) among the lake shales of the Maracangalha Formation (Medeiros and Ponte 1981).

Also associated to the rifte phase, all the syntectonic alluvial fans were observed that formed along the fault system of the east border (fault of edge, responsible for the greater depocenters of the basin), entering sporadically in the basin (Salvador Formation and Member Sesmaria). Thus, bodies of interdigitated conglomerates with shales of the rifte phase are also found (Magnavita 1996).

From the paleoclimatic view, the paleogeographic reconstructions of the continents for the Lower Cretaceous show that the Recôncavo Basin was located in a paleolitude between $15^{\circ} \mathrm{S}$ and $20^{\circ} \mathrm{S}$, that is, within a predominantly tropical climate belt (Parrish and Curtis 1982, Parrish 1985, Scotese et al. 1988). The deposition of the shales was conditioned to lacustrine transgressions and regressions, consequence of climatic conditions of greater humidity or greater aridity, respectively.

Widely recognized as a carrier of the source rocks of the Recôncavo Basin, the Candeias Formation has already been the target of several studies (Daniel et al. 1989, Mello et al. 1994, Penteado and Behar 2000, Balbinot and Kalkreuth 2010), including geochemical evaluations, where strata with varying amounts of total organic carbon were recognized, suggesting internal faciological changes in this geological formation. Some outcrops of the Candeias Formation can be found in the Southern Compartment of the basin, this portion being then the focus of the work. The objective of this research is to evaluate the depositional conditions of the Candeias Formation from the geochemical characterization, in contrast to the shales of the Maracangalha Formation, recognizing different organic facies, which propitiate and justify the variable potentialities for hydrocarbon generation.

\section{MATERIALS AND METHODS}

In order to reach the proposed objectives, 23 samples were collected, all of them photographed and cataloged before the previous treatment for the geochemical analysis at Lepetro - Center of Excellence in Geochemistry of the Institute of Geosciences of the Universidade Federal da Bahia (IGEO/UFBA). All samples were analyzed for the determination of total organic carbon (TOC), sulfur and siliciclastic components (insoluble residue (IR), Rock-Eval pyrolysis, chromatography whole oil, evaluation of saturated biomarkers, stable isotopes of oxygen, organic and inorganic carbon, and the characterization of palynofacies.

The samples were collected at three different points in the Southern Compartment of the basin (Fig. 2), previously defined from bibliographic data and well data requested from the Agência Nacional do Petróleo, Gás Natural e Biocombustíveis (ANP).

The first outcrop is located on highway BR324, $\mathrm{km} \mathrm{557,}$ central site, in the vicinity of the city of Santo Amaro (coordinates $12^{\circ} 29^{\prime} 08.7^{\prime \prime} \mathrm{S}, 38^{\circ} 39^{\prime} 45.6^{\prime \prime} \mathrm{W}$ ). At this point, it was possible to observe well-preserved black shales and sampled every $20 \mathrm{~cm}$ in a total of 10 samples (named from 5B1 to $5 \mathrm{~B} 10)$ to investigate possible vertical variations of the geochemical parameters. This outcrop has been described by Magnavita et al. (2005) as belonging to the Gomo Member of the Candeias Formation.

The second outcrop is studied in a drainage near the city of São Francisco do Conde, specifically in the highway BA522, km 9.9 (coordinates 12³7’43.6” S, 38³7’26.5” W). Samples were collected vertically every $30 \mathrm{~cm}$, in a total of 6 specimens, named from $12 \mathrm{~B} 1$ to $12 \mathrm{~B} 6$, with black shales at the base grading gray toward the top of the outcrop, related to the Maracangalha Formation.

At the intersection of the BR324 and BA093 highways around the city of Simões Filho, samples 21B (coordinates $12^{\circ} 46^{\prime} 56.7^{\prime \prime}$ S, 38²4'46.4” W) were collected. Seven shale specimens were taken vertically $30 \mathrm{~cm}$ apart, named from $21 \mathrm{~B} 1$ to 21B7, showing dark shales interspersed with conglomerate lenses, belonging to the Maracangalha and Salvador Formations, respectively.

The beginning of the analytical process was by determination of the TOC and IR, starting from the weighing of $1 \mathrm{~g}$ of the samples ground and sieved at 80 mesh, with subsequent acid attack $(\mathrm{HCl})$, for the removal of the carbonate fraction (decarbonation). The samples were then washed with hot distilled water and oven dried at approximately $80{ }^{\circ} \mathrm{C}$ until constant weight was obtained. After this process, we have the result of IR, defined as the fraction of the sample not eliminated by the acid treatment (siliciclastic fraction). The decarbonated samples were inserted in the LECO $628 \mathrm{CN}$ Elementary Analyzer, to quantify the TOC contents and, in the samples without acid treatment, the determinations of the total sulfur contents were performed on the LECO 628S Elementary Analyzer. For analysis in the Rock-Eval 6 equipment, $100 \mathrm{mg}$ aliquots of the milled samples were sieved at 80 mesh, following a procedure proposed by Espitalié et al. (1977).

The analyzes by whole oil gas chromatography were carried out on the organic extracts of the shales. For the extraction, approximately $50 \mathrm{~g}$ of sample was used in the ASE system, programmed to operate at a temperature of $150^{\circ} \mathrm{C}$, at a pressure of $1,500 \mathrm{psi}$, performing three 15 -minute wash 
cycles for each cycle, with $150 \mathrm{~mL}$ of dichloromethane per sample. The extracts were concentrated in a rotary evaporator and analyzed in a gas chromatograph and Agilent $7890 \mathrm{~B}$ flame ionization detector (FID) using a DB-1 fused silica capillary column $(15 \mathrm{~m} \times 0.25 \mathrm{~mm} \times 0.25 \mu \mathrm{m})$. The conditions of analysis were: oven temperature $40^{\circ} \mathrm{C}$ for $2 \mathrm{~min}$ and heating ramp $10^{\circ} \mathrm{C} / \mathrm{min}$ to $300^{\circ} \mathrm{C}$, remaining for $12 \mathrm{~min}$; injector and detector temperature at $300^{\circ} \mathrm{C}$, hydrogen as entrainment gas, at $1 \mathrm{~mL} / \mathrm{min}$, constant flow; solution concentration of $0.05 \mathrm{mg}$ sample $/ 1 \mu \mathrm{L}$ dichloromethane, $1 \mu \mathrm{L}$ injection volume.

The analysis of the saturated biomarkers was done after the organic extracts were fractionated by liquid chromatography. The saturated compounds were obtained using n-hexane maintaining the ratio of $1 \mu \mathrm{L}$ solvent for each $0.05 \mathrm{mg}$ extract. Saturated biomarkers were quantified by gas chromatography coupled to mass spectrometry (GC/MS) on Agilent model 7820A equipment equipped with DB-5 fused silica capillary column $(60 \mathrm{~m} \times 0.25 \mathrm{~mm} \times 0.25 \mu \mathrm{m})$. Helium was used as drag gas with flow rate of $1 \mathrm{~mL} / \mathrm{min}$ and constant pressure of $30 \mathrm{psi}$. Sample concentration of $0.05 \mathrm{mg}$ sample $/ 1 \mu \mathrm{L}$ hexane, $1 \mu \mathrm{L}$ injection volume, heating from 60 to $310^{\circ} \mathrm{C}$ with $2^{\circ} \mathrm{C} / \mathrm{min}$ heating ramp.

For the $\delta^{13} \mathrm{C}$ ratio of the organic fraction, aliquots were used with approximately $50 \mathrm{mg}$ of the decarbonated samples, which were then adequately packed in tin capsules and analyzed in Isotope Reason Mass Spectrometry (IRMS) system. The determinations of isotopic ratios $\delta^{13} \mathrm{C}$ and $\delta^{18} \mathrm{O}$ of the inorganic fraction were also made by IRMS using $50 \mathrm{mg}$ samples macerated and sieved at 250 mesh, through the system of automatic analisys of "Bench Gas" carbonate samples.

For characterization of the palynofacies, the isolation of the organic content of the samples was done through successive acidifications to remove carbonic and siliciclastic components using $\mathrm{HCl}$ and $\mathrm{HF}$, respectively, in $20 \mathrm{~g}$ of sample sizes between 2.8 and $1.0 \mathrm{~mm}$, as described by Tyson (1995). To assemble the slides, a drop of the isolated kerogen, dilute acacia gum solution and a drop of distilled water was used on the cover slip. The material was plate heating at $40^{\circ} \mathrm{C}$ for drying. In a blade, it was placed Entellan and the coverslip with the kerogen. The evaluation and analysis of the slides were performed using Zeiss microscope model A2m.

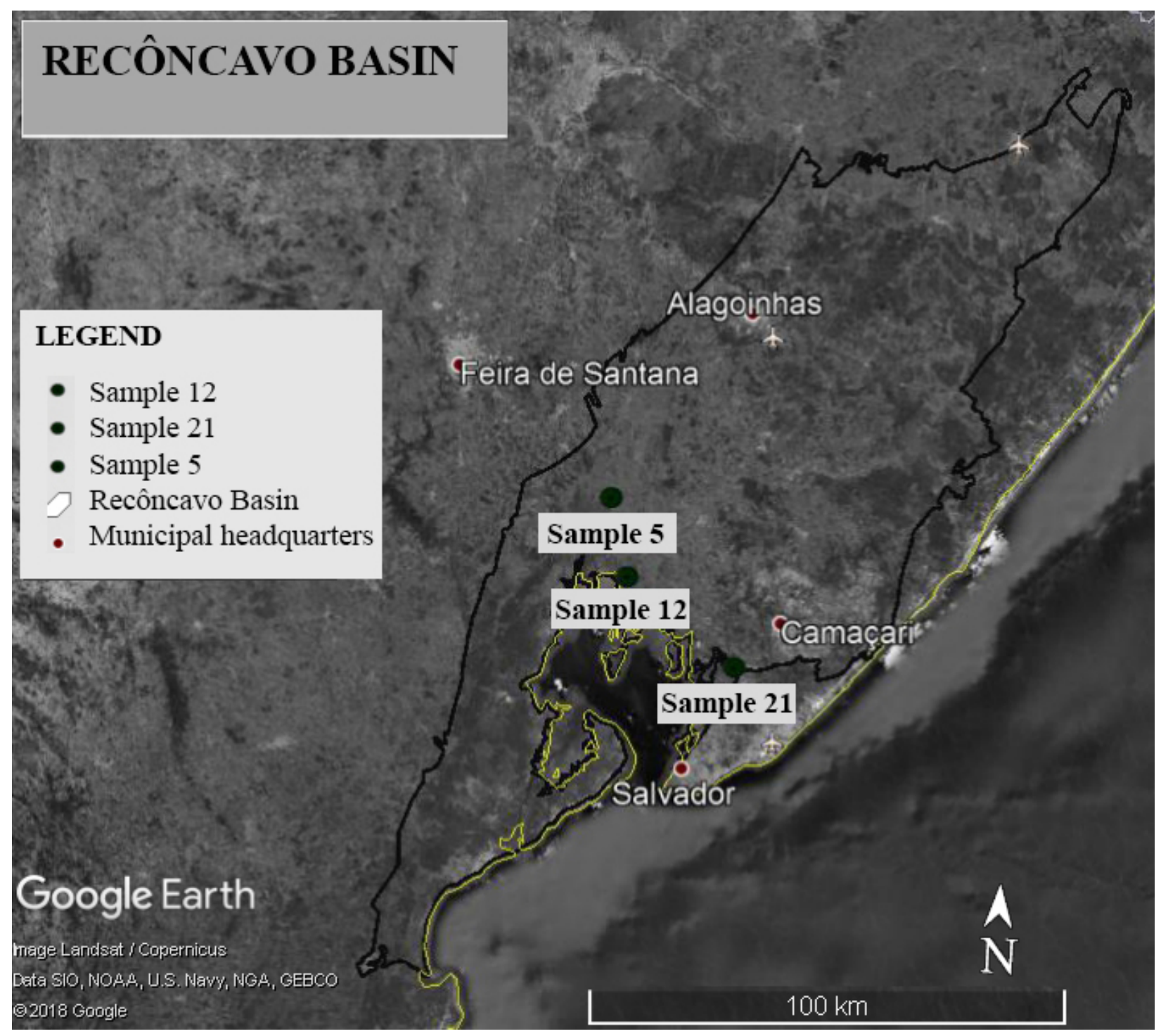

Source: modified from Google Earth (2018).

Figure 2. Satellite view with points visited in the field campaign in the Southern Compartment of the Recôncavo Basin. 


\section{RESULTS AND DISCUSSION}

The TOC contents found in the collected samples varied between $0.06 \%$ and $6.77 \%$, thus making a great difference in the conditions of production and / or preservation of the organic matter, as shown in Table 1. These values allow to frame the samples as having low to high potentials for hydrocarbon generation, as defined by Peters and Cassa (1994). The IR values ranged from $68.49 \%$ to $91.01 \%$, indicating changes in the depositional paleoenvironment, which is favored by mixed sedimentation (values below and close to $70 \%$ of IR, represented by marl and carbonate shale), or by predominantly siliciclastic sedimentation (values greater than $70 \%$, represented by shales with low associated carbonate), according to Figure 3.

As shown in Figure 4, the sulfur contents close to zero are compatible with the proposal of lacustrine (non-marine) continental deposition.

Table 1. TOC and Rock-Eval pyrolysis parameters of samples from the outcrops in Southern Compartment of the Recôncavo Basin

\begin{tabular}{lccccccc}
\hline \multirow{2}{*}{ Sample } & \multirow{2}{*}{ TOC } & \multicolumn{7}{c}{ Rock-Eval pyrolysis } \\
\cline { 3 - 8 } 5B1 & 5.91 & 0.35 & 27.11 & 0.48 & 434 & 625 & 2 \\
5B2 & 6.77 & 0.47 & 29.86 & 0.35 & 437 & 646 & 8 \\
5B3 & 2.35 & 0.12 & 7.48 & 0.07 & 438 & 418 & 4 \\
5B4 & 3.51 & 0.21 & 14.06 & 0.11 & 438 & 511 & 4 \\
5B5 & 2.15 & 0.11 & 7.07 & 0.1 & 436 & 386 & 5 \\
5B6 & 0.63 & 0.04 & 1.41 & 0.05 & 412 & 193 & 7 \\
5B7 & 0.83 & 0.05 & 2.1 & 0.1 & 414 & 221 & 11 \\
5B8 & 1.12 & 0.08 & 3.3 & 0.09 & 416 & 270 & 7 \\
5B9 & 3.32 & 0.19 & 9.66 & 0.25 & 415 & 451 & 12 \\
5B10 & 2.16 & 0.09 & 5.36 & 0.12 & 415 & 375 & 8 \\
12B1 & 0.30 & 0.03 & 0.6 & 0.01 & 430 & 90 & 1 \\
12B2 & 0.24 & 0.01 & 0.21 & 0.23 & 432 & 88 & 96 \\
12B3 & 0.13 & 0.01 & 0.15 & 0.15 & 434 & 115 & 115 \\
12B4 & 0.19 & 0.01 & 0.18 & 0.15 & 432 & 95 & 79 \\
12B5 & 0.12 & 0.01 & 0.13 & 0.13 & 435 & 108 & 108 \\
12B6 & 0.16 & 0.02 & 0.19 & 0.18 & 430 & 119 & 112 \\
21B1 & 1.14 & 0.01 & 0.49 & 0.09 & 429 & 120 & 22 \\
21B2 & 0.34 & 0.02 & 0.5 & 0.47 & 428 & 111 & 104 \\
21B3 & 0.32 & 0.02 & 0.55 & 0.13 & 428 & 131 & 31 \\
21B4 & 0.29 & 0.01 & 0.5 & 0.16 & 427 & 119 & 38 \\
21B5 & 0.27 & 0.02 & 0.52 & 0.18 & 431 & 141 & 49 \\
21B6 & 0.33 & 0.02 & 0.72 & 0.24 & 434 & 133 & 44 \\
21B7 & 0.06 & 0.01 & 0.28 & 0.2 & 435 & 147 & 105 \\
\hline & & & & & & &
\end{tabular}

The parameters provided by the Rock-Eval pyrolysis also depict variations in the samples in study. It is possible to observe that the samples with the highest values of hydrocarbon potential (S2) are those with higher TOC levels (Fig. 5).

The potential variations for hydrocarbon generation suggest different depositional conditions for the formations in case. It is observed that there are good conditions of production and preservation of the organic matter with consequent good

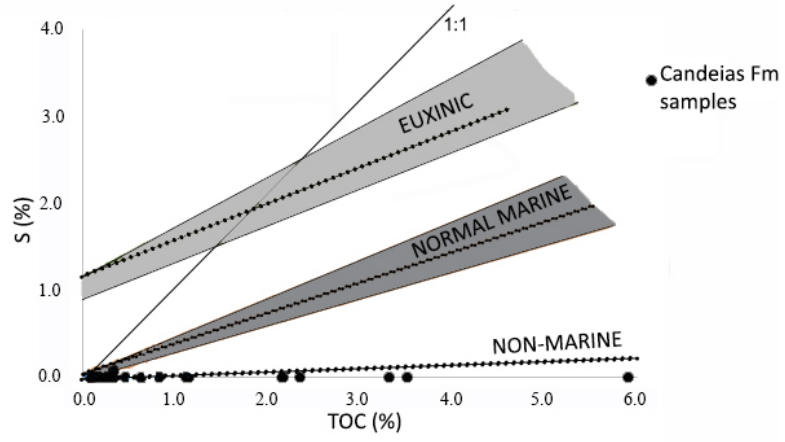

TOC: total organic carbon.

Source: modified from Berner and Raiswell (1983).

Figure 4. Sulfur $(S)$ x TOC ratio with paleoenvironmental indication for the samples of the outcrops in Southern Compartment of the Recôncavo Basin.

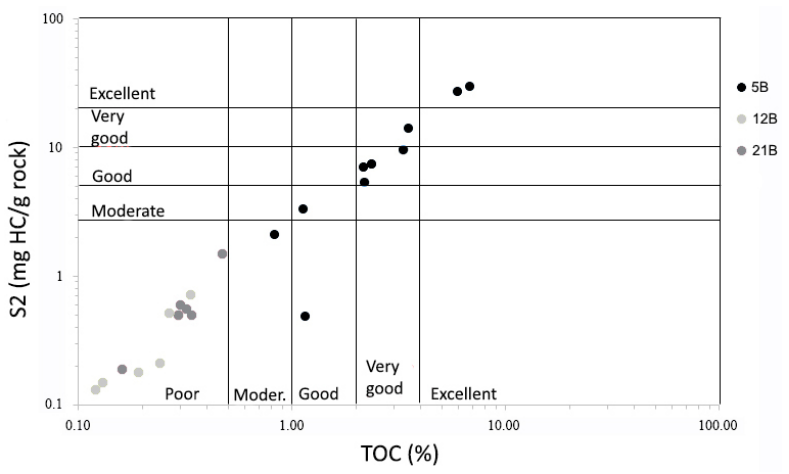

TOC: total organic carbon.

Source: adapted from Peters and Cassa (1994).

Figure 5. Classification of the potential for hydrocarbon generation as a function of the S2xCOT ratio of samples from the outcrops in Southern Compartment of the Recôncavo Basin.
Samples 5B

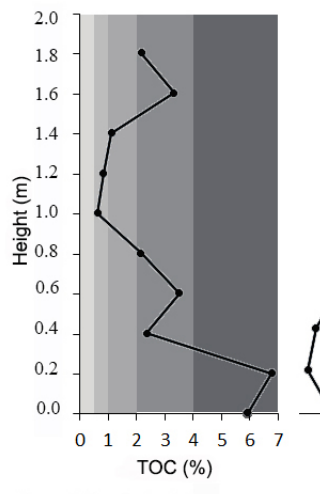

Graphic subtitle

Excellent

Very high
Samples 12B

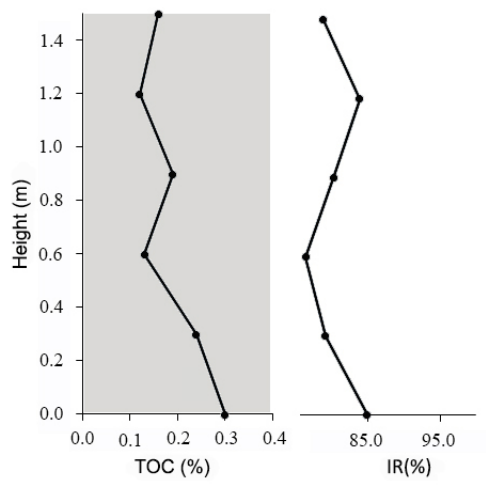

Medium Poor
Samples 21B

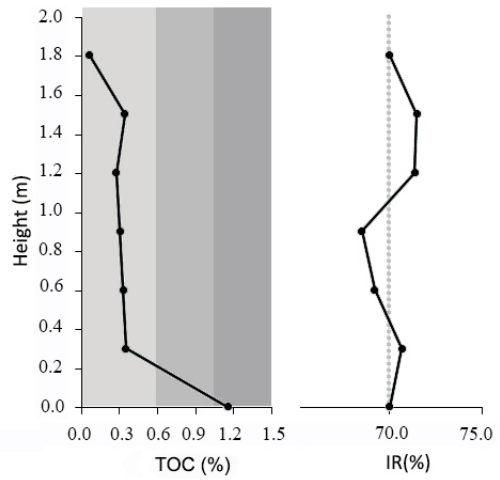

TOC: total organic carbon; IR: insoluble residue.

Figure 3. Total organic carbon $x$ insoluble residue ratio of the samples under analysis of the outcrops in Southern Compartment of the Recôncavo Basin. 
generating potential, and, in some moments, conditions not favorable for the preservation of the organic matter, resulting in layers with little or no potential for hydrocarbon generation.

Layers rich in organic content were previously associated with the Candeias Formation, reported by Brandão (2015), Balbinot and Kalkreuth (2010), Penteado and Behar (2000). These authors identified, from the analysis of cores, richer levels of TOCs, as well as alternating lithotypes, with layers of shales, siltstones and alternating sandstones.

The good potential of samples 5B (Candeias Formation) and the absence of potential of samples 12B and 21B (Maracangalha Formation) is justified by the quality of the organic matter present in each of them, according to the $\mathrm{S} 2 \mathrm{vs}$. TOC kerogen type diagram (Fig. 6). Note that the kerogen present in samples $5 \mathrm{~B}$ is in the type II field and for the other outcrops is in type III/IV field. This suggests that samples with type III/ IV kerogen contain essentially remobilized or highly oxidized organic matter, mentioning the thermal immaturity of the samples $\left(\operatorname{Tmax}<440^{\circ} \mathrm{C}\right)$. Penteado and Behar $(2000)$ report the existence of less rich portions of organic matter possibly as a result of partial alteration by oxidizing conditions in the depositional environment, justifying type IV of the kerogen observed in the present work.

The variations of the oxy-reductive conditions are observed from some ratios among biomarkers compounds, such as Pristane/ Phytane $(\mathrm{Pr} / \mathrm{Ph})$, seen in Table 2. An anoxic environment for

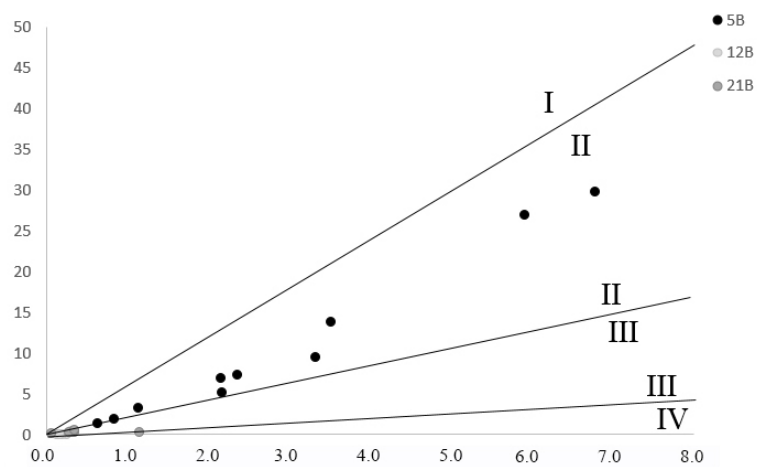

Source: adapted from Langford; Blanc-Valeron (1990).

Figure 6. Samples of outcrops in Southern Compartment of the Recôncavo Basin, plotted in a S2 vs. TOC kerogen type diagram.

Table 2. Reasons calculated using Pristane and Phytane isoprenoids from samples collected from outcrops in Southern Compartment of the Recôncavo Basin.

\begin{tabular}{|c|c|c|c|c|c|}
\hline Samples & $\mathbf{P r} / \mathbf{P h}$ & CPI & Samples & $\mathbf{P r} / \mathbf{P h}$ & CPI \\
\hline $5 \mathrm{~B} 1$ & 0.72 & 1.91 & $12 \mathrm{~B}$ & 0.57 & 1.5 \\
\hline $5 \mathrm{~B} 2$ & 0.74 & 1.88 & $21 \mathrm{~B} 1$ & 1.17 & 1.43 \\
\hline $5 \mathrm{~B} 3$ & 0.77 & 1.77 & $21 \mathrm{~B} 2$ & 1.12 & 1.43 \\
\hline $5 B 4$ & 0.75 & 1.82 & $21 \mathrm{~B} 3$ & 1.20 & 1.41 \\
\hline $5 B 5$ & 0.83 & 1.68 & $21 B 4$ & 1.38 & 1.4 \\
\hline $5 \mathrm{~B} 6$ & 0.91 & 1.53 & $21 \mathrm{~B} 5$ & 1.40 & 1.38 \\
\hline $5 B 7$ & 1.07 & 1.43 & $21 \mathrm{~B} 6$ & 1.24 & 1.44 \\
\hline $5 B 8$ & 1.09 & 1.35 & & & \\
\hline $5 B 9$ & 1.11 & 1.32 & & & \\
\hline $5 B 10$ & 1.12 & 1.12 & & & \\
\hline
\end{tabular}

base-to-top oxide in outcrop 5B, anoxic conditions at the base of outcrop 12B and upward trends in outcrop 21B.

Evaluating the diasterane/sterane ratio it is also possible to note this variation of oxidizing aspects, since the formation of the diastereals is conditioned by the high Eh of the environment. Relating this ratio to pristane/phytane, we can distinguish two groups of samples, interpreted as being deposited under anoxic and oxic conditions (Fig. 7).

It appears that the condition of higher oxidation is reflected by the higher concentrations of carbonate minerals (Fig. 8), since these are deposited under particular conditions of temperature, water oxygenation level, $\mathrm{pH}$, among other factors. This conclusion is reinforced by the C29/C30 hopanes ratio (Fig. 9), indicative of carbonaticity, according to Peters et al. (2005).

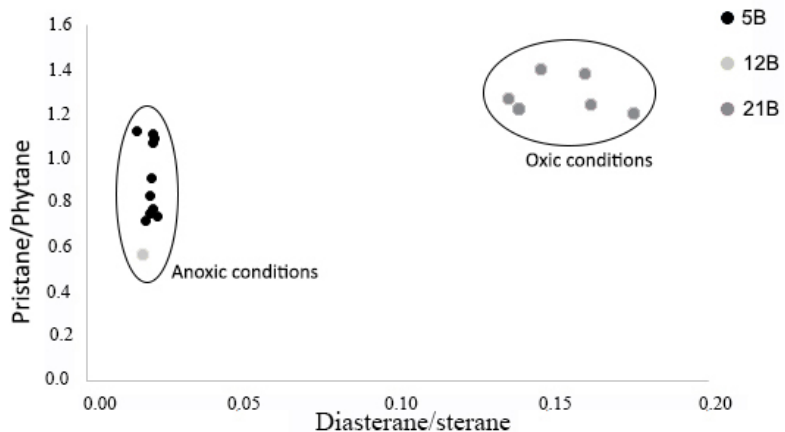

Figure 7. Relation between the Pristane/Phytane and diasterane/ sterane ratios for the samples collected from outcrops in Southern Compartment of the Recôncavo Basin.

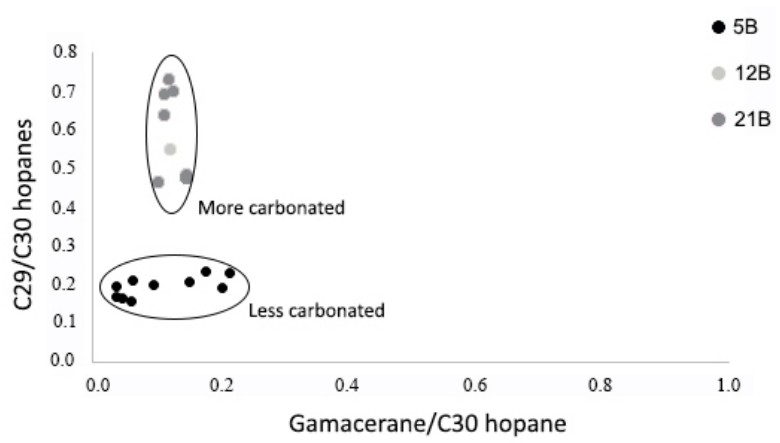

Figure 8. C29/C30 hopanes ratio indicates change in alkalinity in the depositional environment for the samples collected from outcrops in Southern Compartment of the Recôncavo Basin.

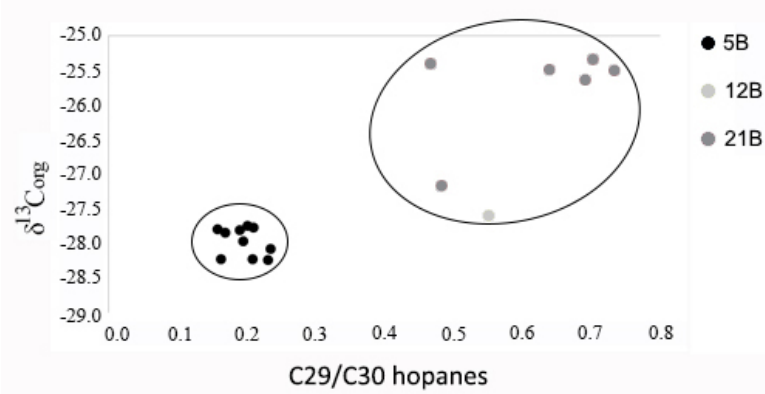

Figure 9. Relation between $\delta^{13} \mathrm{C}$ and $\mathrm{C} 29 / \mathrm{C} 30$ hopanes of the samples collected from outcrops in Southern Compartment of the Recôncavo Basin. 
In the case of a freshwater lake, the low values for the Gamacerane/C30hopano ratio (maximum of 0.2) were expected and are compatible with those reported by Gaglianone and Trindade (1988) for several oils from the Recôncavo Basin.

Relating the values of $\delta^{13} \mathrm{C}$ of the organic matter to the ratio C29/C30 hopanos (Fig. 10), it is notorious that the samples $5 \mathrm{~B}$, deposited in a less oxidizing environment, fresh water, present the most negative values of $\delta^{13} \mathrm{C}$, in agreement with the proposal of Mello et al. (1988), reaffirming that organic matter of sweet lacustrine origin registers heavily negative values of $\delta^{13} \mathrm{C}(<-28 \%$ ), since its main lipid constituents originating from terrestrial plants and freshwater algae are generally depleted in ${ }^{13} \mathrm{C}$ in relation to plants of salt water.

Another evaluation of the markedly negative values of $\delta^{13} \mathrm{C}$ for samples $5 \mathrm{~B}$ is the incorporation, to the sediments, of methanogenic bacteria, since, according to Hollander et al. (1991), such organisms consume ${ }^{13} \mathrm{C}$ depleted methane in anoxic environments. The association of high $\mathrm{IH}$ values with negative values of $\delta^{13} \mathrm{C}$ of the organic matter for this outcrop can be interpreted as resulting from the deposition in a paleoenvironment of freshwater and anoxic water, favorable conditions for the activity of methanogenic organisms.

In contrast, the other samples presented less negative values of $\delta^{13} \mathrm{C}$. There are indications that increased primary productivity may be responsible for positive $\delta^{13} \mathrm{C}$ values of organic matter found in marine and lake sediments. The increase in carbon demand caused by increased productivity reduces the $\mathrm{CO}_{2}$ concentration in the surface waters and the degree of isotopic fractionation, resulting in a biomass progressively enriched in ${ }^{13} \mathrm{C}$ (Deuser 1970, Freeman 1991). However, even if this interpretation is applied to the present study, low IH values and high $\mathrm{IO}$ values allow us to postulate that a possible ${ }^{13} \mathrm{C}$ relative enrichment due to the oxidation of organic matter appears to be reasonable, since several parameters in this work indicate (diasterane/sterane ratio, pristane/phytane ratio) and oxidized organic matter (kerogen type IV in the Van Krevelen type diagram).

Although it presents better preserved or oxidized, the analysis of the molecular parameters indicates that the organic matter present in the outcrops under study has the same source. The interpretation of deposition of the organic matter

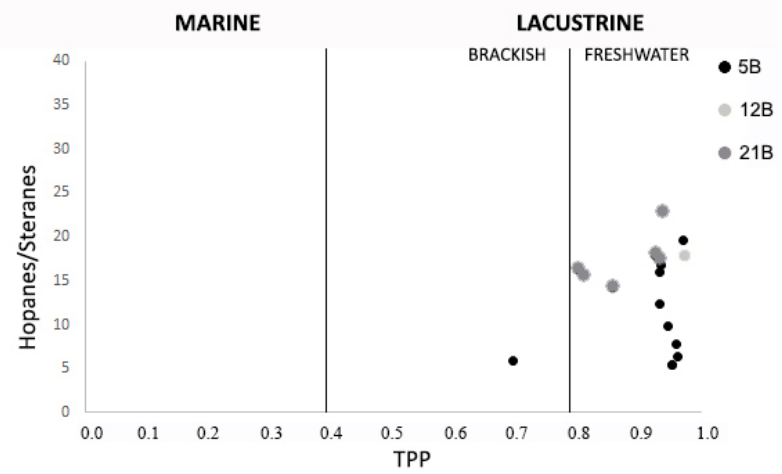

Source: adapted from Holba et al. (2003).

Figure 10. Relationship between hopanos/sterane and tetracyclic polyprenoids (TPP) ratios for the samples collected from outcrops in Southern Compartment of the Recôncavo Basin. in lacustrine context is explicit by the high values of the ratio hopanes/steranes (between 5 and 25), common in oils of non-marine origin. The values of CPI $>1$ (Tab. 2), with predominance of odd n-alkanes, are also typical of hydrocarbons generated by lacustrine organic matter.

The deposition condition in the lacustrine environment is corroborated by the relationship between TPP/TPP + DIA (tetracyclic polypeptides and diasteranes) and hopanes/sterans ratio (Fig. 11), since high relative concentrations of TPPs in oils and rocks generators indicate deposition in lacustrine freshwater/brackish environments (Holba et al. 2003).

There is also a predominance of long-chain n-alkanes, with an average abundance between n-C20 and n-C30, with higher peaks in n-C21, n-C23, n-C25 and n-C27, indicating a preferential contribution of organic matter from freshwater algae, which correlates with the Rock-Eval pyrolysis results, which indicate types I and IV kerogens, the latter most likely resulting from type I oxidation.

High concentrations of tricyclic terpanes corroborate the suggestion of the presence of algae, and the tricyclic/hopanos ratio indicates a richness in Tasmanites (green algae, primitive) (Requejo et al. 1994) (Fig. 11).

The higher contribution of the algae in outcrop $5 \mathrm{~B}$ is observed, being this the one that exhibits higher values of TOC and elevated levels of hydrogen, whereas in the other outcrops this contribution does not seem so significant, possibly due to the non-preservation of the same ones, since they exhibit low values for the hydrogen index and high values for the oxygen index.

The presence of algae and continental constituents is also indicated by the higher concentrations of the regular sterols C27 and C29 in relation to C28 (Fig. 12), being the first derivative of the lacustrine phytoplankton, while the second indicates contributions of superior vegetal material, compatible with the proposal de Mello et al. (1988).

The palynofacies analysis resulted in interpretations similar to those already presented for the characterization of the organic matter present in the different outcrops. However, there are also dissimilar features, reinforcing the assertion about the changes in the depositional conditions of the samples under study.

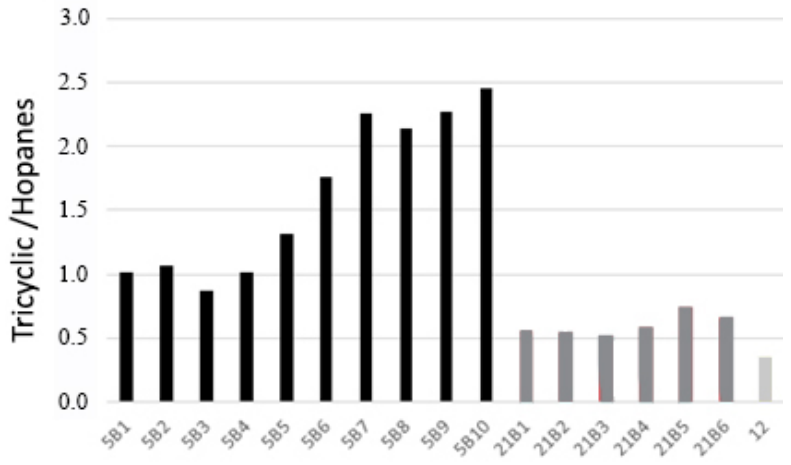

Figure 11. Graph with values for tricyclic/hopanes ratio for the samples collected from outcrops in Southern Compartment of the Recôncavo Basin. 
In the samples of the present work, there is predominance of amorphous organic matter (AOM), accounting for almost all samples values above $90 \%$ of the total components. Phytoclasts occupy the second place in the total percentage, although in low quantities (average of 5\%), among which there is a predominance of the opaque group. The palynomorphs, in turn, are in smaller percentage in the majority of the samples (average of 3\%), being represented mainly by spores and algae, according to the Figure 13.

Outcrop 5B presents in all samples more than $95 \%$ of $A O M$, showing gradation in organic matter preservation levels, showing a better state of preservation at the base and decreasing this state towards the top, since the intensity of the fluorescence changes from yellow -green to yellowish-brown in this direction of the outcrop (Fig. 14). This change is compatible with pristane/phytane ratio values, which show values lower than 1 at the base and near 1 at the top (Tab. 2).

Outcrops 12B show the highest variation in the relative proportions of organic constituents, starting with approximately $97 \%$ of AOM, $1.5 \%$ of palynomorphs and phytoclasts in the base, and $39 \%$ of AOM, $21 \%$ of palynomorphs and $40 \%$

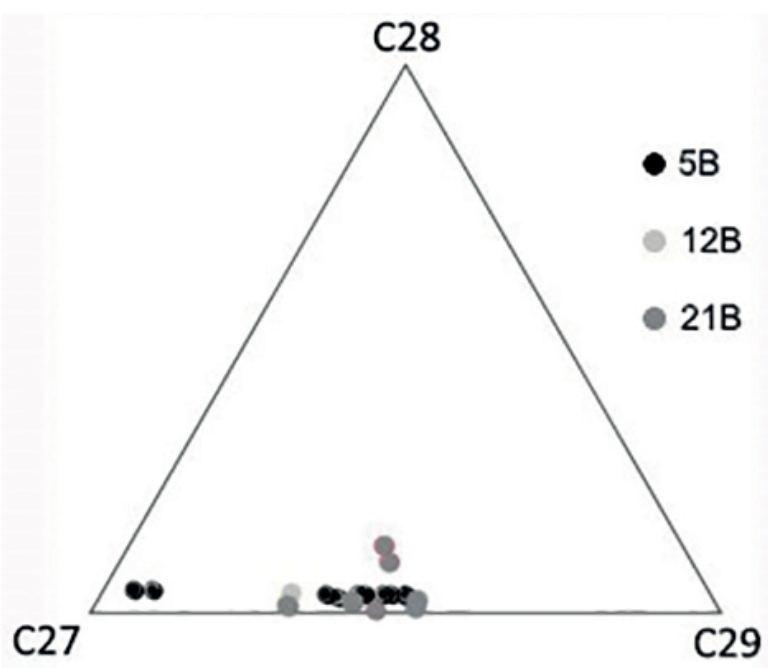

Figure 12. Tertiary diagram between C27, C28 and C29 steranes for samples collected from outcrops in Southern Compartment of the Recôncavo Basin.

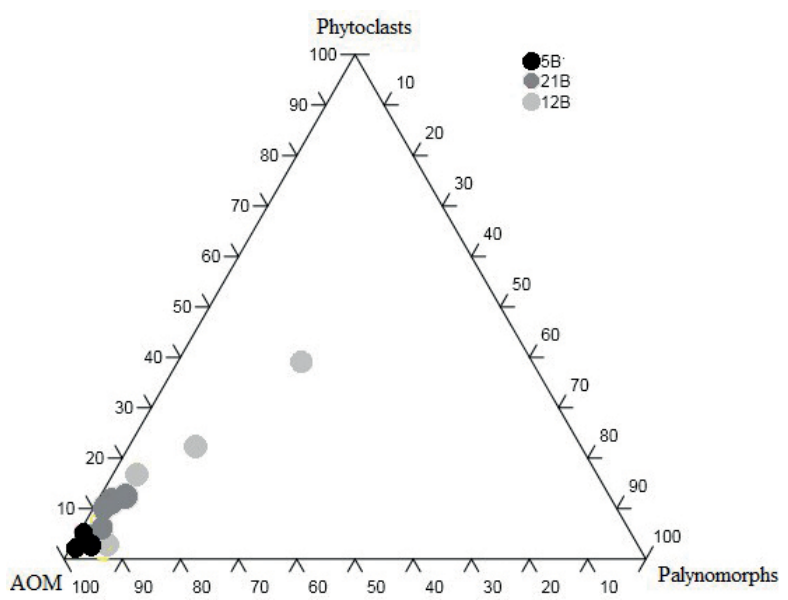

Figure 13. Relative proportions between organic constituents for samples collected from outcrops in Southern Compartment of the Recôncavo Basin. of phytoclasts on the top. Such a difference may represent a fluvial development for the formerly deep portions of the lake. As for the degree of preservation, the section is strongly oxidized from the base to the top, with predominantly brown fluorescence for all the observed particles (Fig. 15).

In outcrop $21 \mathrm{~B}$, the relative proportions of organic components are more homogeneous, exhibiting approximately $90 \%$ of MOA, $7 \%$ of phytoclasts and 3\% of palynomorphs throughout

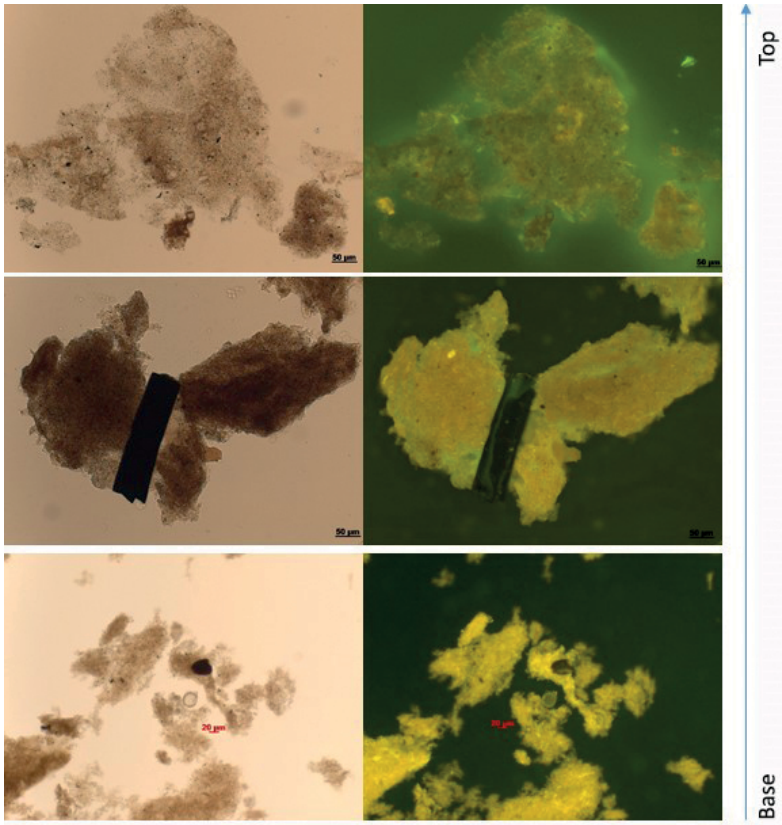

Figure 14. Photographic print of the palynofaciologic laminae of the outcrop 5B, Candeias Formation, Southern Compartment of the Recôncavo Basin. Images left in white light, and right under ultraviolet light, with fluorescence ranging from yellowish-green to yellowish-brown, from the base to the top of the outcrop.

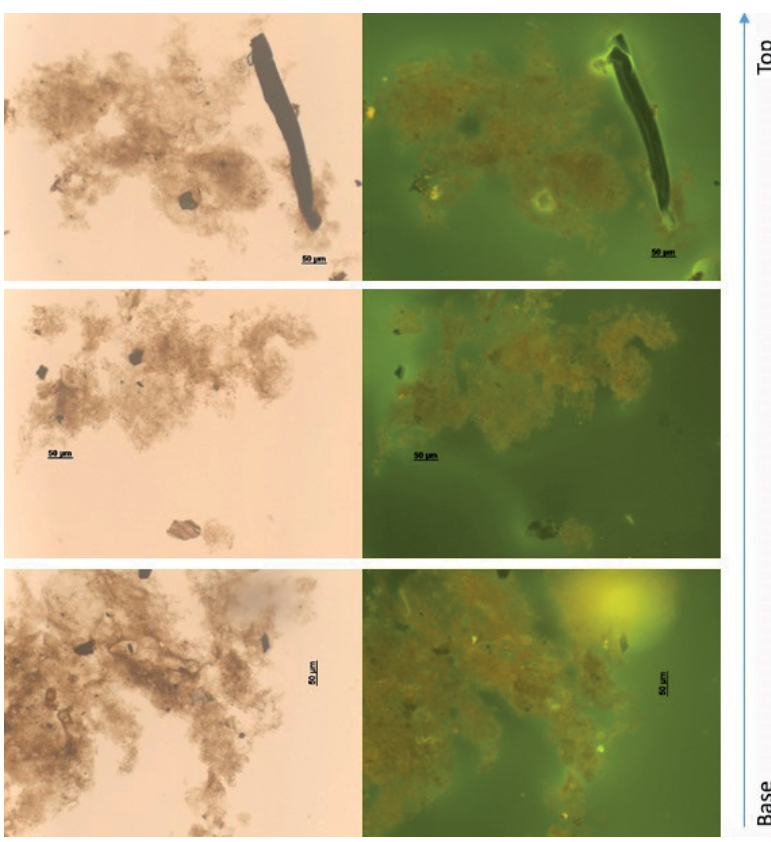

Figure 15. Photographic print of the palynofaciologic laminae of outcrop 12B, Maracangalha Formation, Southern Compartment of the Recôncavo Basin. Images left in white light, and right under ultraviolet light, with fluorescence brown throughout the entire section. 
the section (Fig. 16). Regarding the degree of preservation, the samples present predominantly brown fluorescence, but with better preserved levels (yellowish-brown fluorescence).

From the correlation of the organic geochemistry data with those of palinofacies it is possible to distinguish between different paleoenvironments and depositional conditions, according to the organic facies of Tyson (1995), represented in Figure 17.

The samples of this work are delimited mainly by field IX, supposing depositional environment of distal basin in suboxic-anoxic condition. Tyson (1995) generically defines this environment as deep water deposits or deposits of stratified water column sediments or hungry basin sediments, with

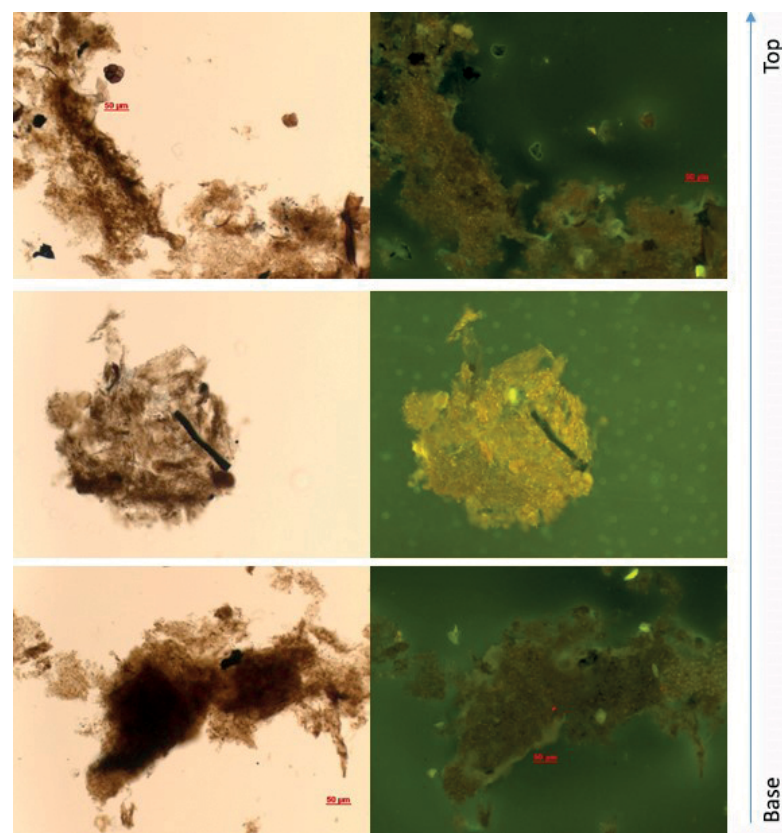

Figure 16. Photographic print of the palynofaciologic laminae of the outcrop 21B, Maracangalha Formation, Southern Compartment of the Recôncavo Basin. Images left in white light, and right under ultraviolet light, with predominant brown fluorescence throughout the section, but with levels showing yellowish intensity.

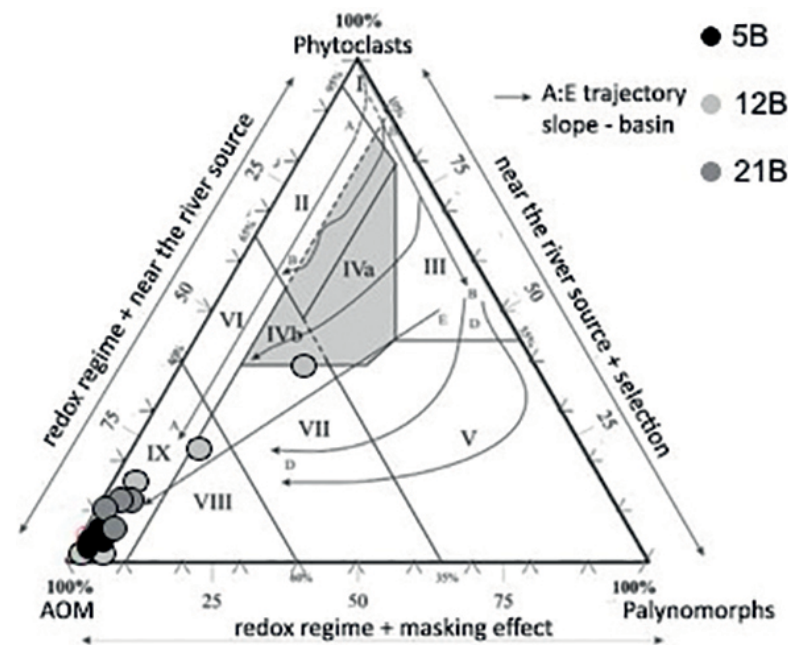

AOM: amorphous organic matter.

Figure 17. Samples plotted in ternary diagram with respect to the different depositional paleoenvironments of the samples collected in outcrops in Southern Compartment of the Recôncavo Basin. the contribution of dominant AOM, low content of palynomorphs, often rich in alginites. Although the samples of the three outcrops under study are represented in the same field, the data of organic geochemistry with those of palynofacies allow a more accurate distinction in terms of organic facies.

The samples from outcrop 5B presented TOC values between 0.63 and $6.77 \%$, high values for the hydrogen index and consequently high values of S2, predominance of AOM with yellow-green bloom, and biomarkers data indicating anoxic conditions in the depositional environment. These characteristics allow to fit these samples into the facies $A B$ Jones (1987), defined as laminate facies, rich in organic content, organic matter almost exclusively composed of components derived from algae and/or bacteria; persistent anoxia in the water column.

Outcrops samples $12 \mathrm{~B}$ and $21 \mathrm{~B}$ show low TOC values (mean of $0.31 \%$ ), high values for oxygen index and low values of $\mathrm{S} 2$, brown fluorescence MOA, and biomarkers data that point to the oxic conditions in the depositional environment. Thus, these samples fit into the facies D of Jones (1987), which is defined as facies with highly oxidized or redeposited residual organic matter.

Lacustrine water bodies are more susceptible to environmental changes, presenting lateral and vertical variations of facies more abrupt than those shown by the marine basins (Soreghan and Cohen 1996). In this context, climatic changes can exert an effective control in the genesis of the sedimentary facies and the conditions of deposition and preservation of the organic matter in lacustrine registries. Based on this assumption, the faciological differences observed in the present study indicate that climatic cycles have acted to the time of deposition of lake shales.

Differences in water balance (inflow versus evaporation) can be expressed in rocks of lacustrine origin through variations of the $\delta^{18} \mathrm{O}$ data of the carbonate fraction. Given the isotopic fractionation process, with preferential removal of the lighter isotope $\left({ }^{16} \mathrm{O}\right)$, during evaporation, variations of the $\delta^{18} \mathrm{O}$ values in lacustrine carbonates may reflect the succession of wetter or more arid periods during sedimentation. It is noted ${ }^{18} \mathrm{O}$ enriched carbonates deposit under arid conditions, while a relative enrichment at ${ }^{16} \mathrm{O}$ in the water depth is observed at more humid times. The values of $\delta^{18} \mathrm{O}$ in the carbonate fraction of the samples analyzed illustrate variations (Tab. 3) that are considered related to climatic seasonalities.

In samples from outcrop 5B, the isotopic data illustrates a relative enrichment at ${ }^{18} \mathrm{O}$, expressed by positive values of $\delta^{18} \mathrm{O}$, suggesting that the associated carbon fraction has deposited under arid conditions. The organic content of the samples stands out from the other outcrops, with values up to $6.77 \%$, due to conditions more favorable to the production and preservation of organic matter. Probably, the respective samples represent the Deep Lake Facies defined by Carrol and Bohacs (1999) to cover fresh/brackish facies, with predominantly type I kerogen.

Alongside the tectonic influence, climate control in lake systems of rifte basins has great relevance. Under arid climate and reduced water inflow, conditions conducive to the stratification of the water body, the development of background 
anoxia and the consequent preservation of organic matter are created, a context interpreted for the outcrop samples 5B.

Santos (2005), in a study of the fluvio-delta-lacustrine cycles that characterize the Barremian in the Recôncavo Basin, used oxygen isotope data in the carbonate fraction of shales to recognize a climate control on the vertical succession of identified in these cycles (Fig. 18). According to the author, the fluvio-deltaic progression is favored in humid periods, with greater water inflow and elevation of the base level, to which progressively more negative values of $\delta^{18} \mathrm{O}$ are associated. The subsequent reduction of the base level, with the implementation of arid conditions and higher rates of evaporation, would be paralleled by progressively more positive (or less negative) values of $\delta^{18} \mathrm{O}$. Black shales enriched in organic carbon would occupy a specific position in this cycle, according to the author, being related to the initial stage in which the inflow of water and therefore the contribution of terrigenous, for implantation of

Table 3. Isotopic ratio $\delta^{18} \mathrm{O}$ of the carbonate fraction of samples from outcrops in Southern Compartment of the Recôncavo Basin.

\begin{tabular}{lllll}
\cline { 1 - 1 } \cline { 1 - 1 } \cline { 1 - 1 } Sample & $\delta^{18} \mathbf{O}$ & & Sample & $\delta^{18} \mathbf{O}$ \\
\hline 5B1 & 0.90 & & $12 \mathrm{~B} 1$ & -5.61 \\
5B2 & 1.78 & & $12 \mathrm{~B} 2$ & -5.82 \\
5B3 & 1.95 & & $12 \mathrm{~B} 3$ & -4.64 \\
5B5 & 1.49 & & $12 \mathrm{~B} 4$ & -4.38 \\
5B6 & 0.90 & & $12 \mathrm{~B} 5$ & -4.83 \\
5B7 & 0.56 & & $12 \mathrm{~B} 6$ & -4.58 \\
5B8 & 0.00 & & $21 \mathrm{~B} 1$ & -3.55 \\
5B9 & 0.65 & & $21 \mathrm{~B} 2$ & -3.60 \\
5B10 & 0.68 & & $21 \mathrm{~B} 3$ & -4.47 \\
& 2.90 & & $21 \mathrm{~B} 4$ & -4.02 \\
& & $21 \mathrm{~B} 5$ & -4.26 \\
& & $21 \mathrm{~B} 6$ & -4.00 \\
\cline { 1 - 1 } & & $21 \mathrm{~B} 7$ & -3.20 \\
\hline
\end{tabular}

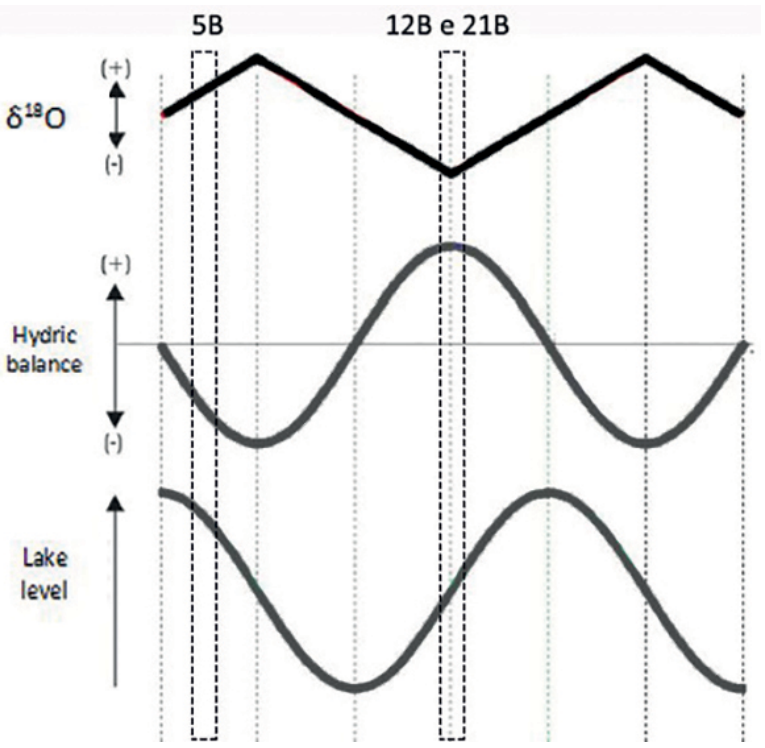

Figure 18. Representation of outcrops in Southern Compartment of the Recôncavo Basin depending on the climatic variations inferred. Source: modified from Santos (2005). a climatic regime with negative water balance ( aridization), with reduction of the base level.

Based on the Santos' (2005) model, the samples from outcrop 5B would testify to this initial context of lake level fall, under negative water balance, represented by more positive values of $\delta^{18} \mathrm{O}$, as indicated in Figure 18. Already the samples of outcrops $12 \mathrm{~B}$ and $21 \mathrm{~B}$, with negative values of $\delta^{18} \mathrm{O}$ (Tab. 3), would register a period with greater water inflow and consequent elevation of the base level (lake level) under a humid climate, leading to a more enriched isotope $\left({ }^{16} \mathrm{O}\right)$ in the water layer and, therefore, in the carbonate fraction of the shales. In the classification of Carrol and Bohacs (1999), the samples of these two outcrops correspond to the Fluvio-lacustrine Facies, representing facies of fresh water/bracken with types I and III kerogen.

A climatic condition of great humidity allows greater river discharges, favoring the influx of nutrients and providing the circulation and consequent oxygenation of the water body. In this case, Gonçalves (2001) argues that the greater influx of fresh water and the more efficient return of nutrients to the photic zone lead to a significant increase in primary productivity, generating a large amount of biomass originated mainly by the relatively enriched ${ }^{13} \mathrm{C}$ (compatible with that shown in Fig. 9). On the other hand, with the expansion of the oxic part of the water column, the conditions of preservation of the organic matter worsen. As a result, rocks with low levels of organic carbon and strongly oxidized organic matter are formed. This would be the depositional context of the samples related to outcrops $12 \mathrm{~B}$ and $21 \mathrm{~B}$, as opposed to the conditions of stratified lake and good preservation of the organic matter exemplified by outcrop 5B.

An alternative view for the facies sampled in outcrops $12 \mathrm{~B}$ and $21 \mathrm{~B}$ would be their deposition in shallower and wider portions of the lake, which is also consistent with the variation of the TOC contents in these outcrops.

\section{CONCLUSIONS}

The results obtained in the present study suggest that climatic seasonalities play a predominant role in the control of variations in the geochemical properties of organic matter in lacustrine shales of the Recôncavo Basin. As consequence, different organic facies are developed, with different potentials for hydrocarbon generation.

In the same period, it was observed that the water content of the Barremian section of the Recôncavo Basin was similar to that proposed by Santos (2005). The deposition of black shales, with higher organic content, would be favored in periods with negative water balance (more arid), similar to the model proposed by Santos (2005).

Outcrop samples $5 \mathrm{~B}$ are those with the highest TOC, MO of type I well preserved, derived from organic matter deposited predominantly under anoxic conditions, with greater potential for hydrocarbon generation. The facies evaluated identify the most favorable context for the production and preservation of organic matter at the time of deposition of the Candeias Formation. A deep and stratified lake environment 
is interpreted under arid climate. The inflow of water through fluvio-delta systems would be ephemeral or lack sufficient energy to reach distal portions of the lake and promote effective circulation of the water column.

The other outcrops, $12 \mathrm{~B}$ and $21 \mathrm{~B}$, are those with low TOC values, residual kerogen, type IV (oxidized), derived from organic matter deposited predominantly under oxidizing conditions, with little or no potential for hydrocarbon generation. The facies sampled suggest a context of high rates of primary production (as the less negative values of $\delta^{13} \mathrm{C}$ of organic matter), but in an environment that did not favor the preservation of organic matter, possibly due to the greater circulation of water in the lake, efficient stratification, making it oxidizing throughout the water column. In the context of humid climate, another possibility is that such layers have been deposited in a transgressive lake regime, reaching shallow portions of the basin, causing oxidation of the organic matter present therein.

\section{ACKNOWLEDGMENT}

The authors are grateful to the Post-Graduate Program in Geochemistry: Petroleum and Environment (Pospetro) of the Universidade Federal da Bahia, for all the support during the preparation of this article. Thanks also to the Agência Nacional do Petróleo, Gás Natural e Biocombustíveis (ANP) for the data provided. Finally, the authors are extremely grateful for the valuable observations and suggestions provided by the geologist Paulo Milhomem.

This research was carried out in association with the ongoing R\&D project registered as ANP 20075-8, "Advanced Molecular Characterization" (UFBA/Shell Brasil/ANP) — Project "Pesquisas em Sistemas Petrolíferos de Bacias Sedimentares Brasileiras do Centro de Excelência de Geoquímica do Petróleo do Instituto de Geociências (IGEO) da Universidade Federal da Bahia (UFBA) - GEOQPETROL-BS”, sponsored by Shell Brasil under the ANP R\&D levy as "Compromisso de Investimentos com Pesquisa e Desenvolvimento”.

\section{ARTICLE INFORMATION}

Manuscript ID: 20190058. Received on: 07/16/2019. Approved on: 05/11/2020.

D.A. wrote the first draft of the manuscript and prepared figures and tables; J.C. provided advisory regarding Recôncavo Basin geology, improved the manuscript through corrections and suggestions; C.A. provided information on palynomorphs and environmental interpretations; H.R. provided data on the geology of Recôncavo Basin, revised and improved the manuscript; K.G. provided geochemical information and article review; F.M. contributed with laboratory support, interpretation and improvements in the article; O.O. helped with geochemical information and article review; A.Q. was responsible for geochemical information and article review; L.S. contributed with geochemical information and article review.

Competing interests: The authors declare no competing interests.

\section{REFERENCES}

Balbiot M., Kalkreuth W. 2010. Organic geochemistry and petrology of the Gomo Member, Recôncavo Basin, Brazil. International Journal of Coal Geology, 84(3-4):286-292. https://doi.org/10.1016/j.coal.2010.09.008

Berner R.A., Raiswell R. 1983. Burial of organic carbon and pyrite sulfur in sediments over Phanerozoic time: a new theory. Geochimica et Cosmochimica Acta, 47(5):855-862. https://doi. org/10.1016/0016-7037(83)90151-5

Brandão A.T. 2015. Sedimentologia e estratigrafia dos turbiditos lacustres da Formação Candeias no nordeste da Bacia do Recôncavo, Bahia. 254f. Tese de doutorado, Universidade Federal do Rio Grande do Sul, Porto Alegre.

Caixeta J.M., Bueno G.V., Magnavita L.P., Feijo F.J. 1994. Recôncavo, Tucano and Jatoba Basins. Boletim de Geociencias da Petrobras, 8(1):163-172.

Carrol A.R., Bohacs K.M. 1999. Stratigraphic classification of ancient lakes: balancing tectonic and climatic controls. Geology, 27(2):99-102.

Da Silva H.T.F., Caixeta J.M., Magnavita L.P., Sanches C.P. 2000. Syn-rift lacustrine deep-water deposits: examples from the Berriasian sandy strata of the Recôncavo basin, Northeastern Brazil. In: Gierlowski-Kordesch E.H., Keltz K.R. (Eds.). Lake basins through space and time. AAPG Studies in Geology 46, p. 209-224.

Daniel M.F., Souza E.M., Mato F. 1989. Geoquímica e modelos de migração de hidrocarbonetos no Campo de Rio do Bua Integração com o compartimento nordeste da Bacia do Recôncavo. Boletim de Geociências da Petrobras, 3:201-214.

Deuser W.G. 1970. Isotopic evidence for diminishing supply of available carbon during diatom bloom in the Black Sea. Nature, 225(5237):10691071. https://doi.org/10.1038/2251069a0

Espitalié J., Laporte J.L., Madec M., Marquis F., Leplat P., Paulet J., Boutefeu A. 1977. Méthode rapide de caractérization des roches mères, de leur potentiel pétrolier et de leur degré d'évolution. Revue de l'Institut Français du Pétrole, 32(1):23-43. https://doi.org/10.2516/ogst:1977002
Freeman K.H. 1991. The carbon isotopic compositions of individual compounds from ancient and modern environments. 146f. PhD Thesis, Indiana University, Bloomington.

Gaglianone P.C., Trindade L.A.F. 1988. Caracterização geoquímica dos óleos da Bacia do Recôncavo. Geochimica Brasiliensis, 2(1):15-39. http:// dx.doi.org/10.21715/gb.v1i2.13

Gonçalves F.T.T. 2001. Controles limnológicos sobre a formação de rochas geradoras de petróleo lacustres: o exemplo da Bacia de Camamu, nordeste do Brasil. Geociências, 20(1):5-23.

Google Maps. Google. Bacia do Recôncavo, BA. Available at: https://www. google.com.br/maps/@-11.5242571,-39.5266223,8z. Acessed on: 22 Apr. 2018

Holba A.G., Dzou L.I., Wood G.D., Ellis L., Adam P., Schaeffer P., Albrecht P., Hughes W.B. 2003. Application of tetracyclic polyprenoids as indicators of input from freshbrackish water environments. Organic Geochemistry, 34(3):441-469. https://doi.org/10.1016/S0146-6380(02)00193-6

Hollander D., Behar F., Vandenbrouke M., Bertrand P., Mckenzie J.A. 1991. Geochemical alteration of organic matter in eutrophic Lake Greifen: implications for the determination of organic facies and the origin of lacustrine source rocks. In: Huc A.Y. (Ed.). Deposition of Organic Facies. American Association of Petroleum Geologists, Studies in Geology, 30, p. 181-193.

Jones R.W. 1987. Organic facies. In: Brooks J., Welte D. (eds.). Advances in Petroleum Geochemistry. London, Academic Press, p. 1-90.

Langford, F.F., Blanc-Valleron, M.M. 1990. Interpreting Rock-Evalpyrolysis data using graphs of pyrolizable hydrocarbons vs. total organic carbon. The American Association of Petroleum Geologists Bulletin, 74(6):799-804.

Magnavita L.P. 1996. Sobre a implantação da fase sinrifte em riftes continentais. In: Congresso Brasileiro de Geologia, 39., 1996, Salvador. Anais... São Paulo: Sociedade Brasileira de Geologia, p. 335-338. 
Braz. J. Geol. (2020), 50(3): e20190058

Magnavita L.P., Silva R.R.D.A., Sanches C.P. 2005. Guia de campo da Bacia do Recôncavo, NE do Brasil. Boletim de Geociências da Petrobras, 13:301-334.

Medeiros R.A., Ponte F.C. 1981. Roteiro geológico da Bacia do Recôncavo, Bahia. Salvador: Petrobras/SEN-BA. 63 p.

Mello M.R., Gaglianone P.C., Brassell S.C., Maxwell J.R. 1988. Geochemical and biological marker assessment of depositional environments using Brazilian offshore oils. Marine and Petroleum Geology, 5(3): 205-223.

Mello M.R., Koutsoukos E.Á.M., Mohriak W., Bacoccoli G. 1994. Selected petroleum systems in Brazil. In: Magoon L.B., Dow W.G. (Eds.). The petroleurn system - from source to trap. AAPG Mémoir 60, p. 499-512.

Milhomem P.S., Maman E.J., Oliveira F.M., Carvalho M.S.S., Lima W.S. 2003. Bacias Sedimentares Brasileiras: Bacia do Recôncavo. Fundação Paleontológica Phoenix, ano 5, n. 51.

Parrish J.T. 1985. Global paleogeography, atmospheric circulation, and rainfall in the Barremian Age (late Early Cretaceous). Denver: U.S. Geological Survey. 24 p. (Estados Unidos. Geological Survey. Open-file Report, 85-728).

Parrish J.T., Curtis R.L. 1982. Atmospheric circulation, upwelling, and organicrich rocks in the Mesozoic and Cenozoic eras. Palaeogeography, Palaeoclimatology, Palaeoecology, 40(1-3):31-66. https://doi.org/10.1016/0031-0182(82)90084-0

Penteado H.L.B., Behar F. 2000. Geochemical characterization and compositional evolution of the Gomo Member source rocks in the Recôncavo Basin, Brazil. In: Mello M.R., Katz J.B. (Eds.). Petroleum System of South Margins. Tulsa: American Association of Petroleum Geologists, p. 179-194. Memoir, 73.
Peters K.E., Cassa M.R. 1994. Applied source rock geochemistry. In: Magoon L.B., Dow W.G. (Eds.). The Petroleum System: from Source to Trap. American Association of Petroleum Geologists, p. 93-120. Memoirs.

Peters K.E., Walters C.C., Moldowan J.M. 2005. The Biomarker Guide. Cambridge: Cambridge University Press. v. 2.

Requejo A.G., Wielchowsky C.C., Klosterman M.J., Sassen R. 1994 Geochemical characterization of lithofacies and organic facies in Cretaceous organic-rich rocks from Trinidad, East Venezuela basin. Organic Geochemistry, 22(3-5):441-459. https://doi.org/10.1016/0146-6380(94)90118-X

Santos C.F. 2005. Estratigrafia de Seqüências da fase final de preenchimento de um rifte intracontinental: um modelo com base no Barremiano Inferior da Bacia do Recôncavo. Boletim de Geociências da Petrobras, 13(2):205-226.

Santos C.F., Cupertino J.A., Braga J.A.E. 1990. Síntese sobre a geologia das bacias do Recôncavo Tucano e Jatobá. In: Gabaglia (Ed.). Origem e evolução de bacias sedimentares. Rio de Janeiro, Petrobrás. p. 367-388.

Scotese C.R., Gahagan L.M., Larson R.L.C. 1988. Plate tectonic reconstrutions of the Cretaceous and Cenozoic ocean basins. Tectonophysics, 155(1-4):27-48. https://doi.org/10.1016/0040-1951(88)90259-4

Soreghan M.J., Cohen A.S. 1996. Textural and compositional variability across litoral segments of Lake Tanganika: the effect of asymmetric basin structure on sedimentation in large rift lakes. American Association of Petroleum Geologists Bulletin, 80(3):382-409.

Tyson R.V. 1995. Sedimentary Organic Matter: Organic Facies and Palynofacies. Londres: Chapman \& Hall, 615 p. 